\title{
Age, growth and maturity of the thin-lipped grey mullet, liza ramada in Bardawil lagoon, North Sinai, Egypt
}

\author{
Gaber I. Dessouky ${ }^{1}$, Azza A. El-Ganainy ${ }^{2} *$, Mohamed Salem ${ }^{1}$, Atya El-Aiatt ${ }^{2}$ and \\ Amany A. Mahmoud ${ }^{1}$ \\ 1- Faculty of Environmental Agricultural Sciences, EL-Arish, Suez Canal Univ., Egypt \\ 2- $\quad$ National Institute of Oceanography and Fisheries, Suez, Egypt \\ *Corresponding author e-mail:
}

\begin{abstract}
Age and growth of 599 thin-lipped grey mullet, Liza ramada from the Bardawil lagoon were estimated by ring counts on scalesduring April to December, 2013. Lengths (Lt) ranged between 11.6 to $45.8 \mathrm{~cm}$ and the corresponding weight $(\mathrm{Wt}$ )was 28 to $668 \mathrm{~g}$. All fishes aged from 0 to 6 years, with age $1^{\text {st }}, 2^{\text {nd }}, 3^{\text {th }}$ year being the most dominant age groups. The length-weight relationship indicated negative allometric growth $(b=2.764)$. Backcalculated lengths were $16.9,23.1,28.3,32,35.5$ and $38.3 \mathrm{~cm}$ to ages $1^{\text {st }}, 2^{\text {nd }}, 3^{\text {th }}, 4^{\text {th }}, 5^{\text {th }}$ and $6^{\text {th }}$, respectively. Von-Bertalanffy growth parameters (VBGP) were L $\infty=50.95 \mathrm{~cm}$, $\mathrm{K}=0.1977 \mathrm{yr}^{-1}, \mathrm{t}_{0}=-1.04 \mathrm{yr}^{-1}$. The growth performance index $(\varphi)$ was 2.71. The sex ratio of $L$. ramada in the present study was $\approx 1: 2$ male to female, respectively. The reproductive activity starts in September, while the highest values of GSI were at November and December. The length at first sexual maturity $\left(\mathrm{L}_{\mathrm{m} 50}\right)$ was estimated at $28.6 \mathrm{~cm}(\approx 3.1$ years $)$ and $29.6 \mathrm{~cm}$ $(\approx 3.4$ years $)$ for males and females, respectively.
\end{abstract}

Key words: Thin-lipped grey mullet, Liza ramada, age, growth, maturity, Bardawil lagoon

\section{INTRODUCTION}

In Bardawil lagoon, the fishing operations are seasonally, starting from April to December, sometimes it extends to January. Mullet fishes (Mugilidae) play an increasingly important role in local markets. The thin-lipped grey mullet, $L$. ramadais one of the most common mullet landed and consumed by Egyptian families, where prices of this fishes are lower than any other seafood. Mullets (Mugilidae) are among the most common species from tropical and temperate marine coastal waters in the world and constitute a fundamental protein resource for a number of human populations living in coastal areas (Nelson, 1994). The life history information is the most important study to our understanding of the species biology to enable the control of fishing.

The aim of this work is to study age, growth and maturity of the thin-lipped grey mullet L. ramada. This will provide the required information for the sustainable use of the resource and fishery management in Bardawil lagoon.

\section{MATERIALS AND METHODS}

The study was carried out in Bardawil lagoon (Fig. 1). The lagoon is located in the Sinai Peninsula, Egypt and it covers an area of $693 \mathrm{~km}^{2}$. 
Gaber I. Dessouky et al.

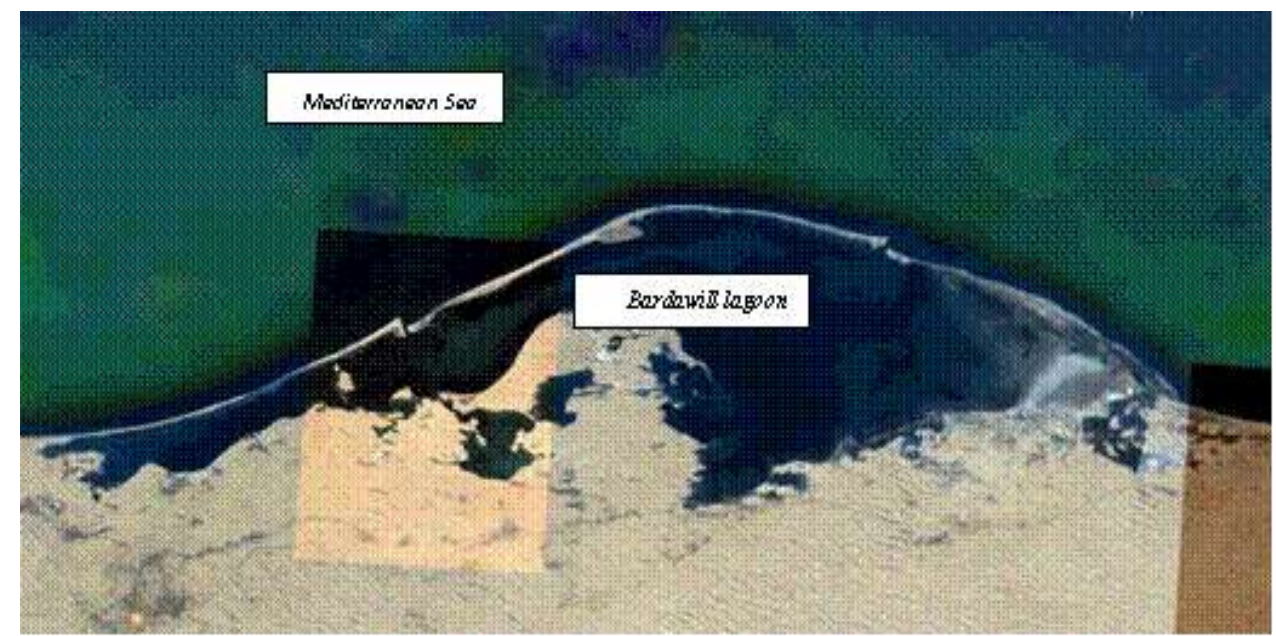

Fig. (1). The Bardawil lagoon

599 specimens of thin-lipped mullet Liza ramada were monthly collected from the landing sites at Bardawil lagoon during April to December 2013. The total length (to the nearest $\mathrm{mm}$ ) and the total weight (to the nearest $0.1 \mathrm{~g}$ ) of all individuals were recorded. The age was determined by scale reading (Paul, 1968). Annual rings on scales were examined under a binocular stereomicroscope at 10 magnifications using reflected light.

The relationship between length and weight was computed using the formula $\mathrm{W}=\mathrm{a} \mathrm{L}{ }^{\mathrm{b}}$ where $\mathrm{W}$ is the total weight in grams, $\mathrm{L}$ is the total length in centimeters and $\mathrm{a} \& \mathrm{~b}$ are constants whose values were estimated by the least square method. The back-calculated lengths to age classes were recorded using Lee's (1910) equation as: $L_{n}\left(S_{n} / S\right) L$ (Where: $L_{n}$ is the total length in centimeters, $S_{n}$ is magnified scale radius to " $n$ "annulus, $S$ is the scales radius in millimeters and $\mathrm{L}$ is the total length in centimeters). The back-calculated weights at the end of each year were estimated by applying the equations of length-weight relationship.

Theoretical growth in length was obtained by fitting the von Bertalanffy growth model, using the Gulland and Holt (1959) method. Von Bertalanffy (1949) for theoretical growth in length can be written in the form: $\mathrm{L}_{\mathrm{t}}=\mathrm{L}_{\infty}\left(1-\mathrm{e}^{-\mathrm{k}(\mathrm{t}-\mathrm{t})}\right)$ (Where: $\mathrm{L}_{\mathrm{t}}=$ the length at age $\mathrm{t}, \mathrm{L}_{\infty}=$ the asymptotic length at $\mathrm{t}_{\infty}, \mathrm{K}=$ growth coefficient and $\mathrm{t}_{0}=$ age at which the length is theoretically nil).

The condition factor $(\mathrm{Kc})$ was calculated by using Hile (1936) formula as: $\mathrm{Kc}=(\mathrm{W} * 100) / \mathrm{L}^{3}$ (Where: $\mathrm{K}$ is the composite coefficient of condition, $\mathrm{W}$ is the total weight in gram and $\mathrm{L}$ is thetotal length in $\mathrm{cm})$.

The growth performance index $(\varphi)$ was estimated as: $\varphi=\log \mathrm{K}+2 \log \mathrm{L}_{\infty}$ (Where: $\mathrm{K}$ and $\mathrm{L}_{\infty}$ are parameters of von Bertalanffy) (Pauly and Munro, 1984).

All Fishes were dissected for sex determination and maturity investigation. When sexual differentiation is not possible, individuals were removed. The gonads after being removed were weighed to the nearest $0.01 \mathrm{~g}$; the monthly gonado-somatic indices (GSI) were calculated by the equation of Bariche et al. (2003) as follows:

GSI $=($ Gonad Weight / (Body Weight - Gonad Weight $))^{*} 100$

During the spawning period, by the naked eyes and by microscopic examination in young specimens, mature individuals were determined.The length at first sexual maturity $\left(\mathrm{L}_{\mathrm{m} 50}\right)$ was 


\section{Age, growth and maturity of the thin-lipped grey mullet, liza ramada in Bardawil lagoon, North Sinai, Egypt}

determined by $50 \%$ of fish which reach their sexual maturity. Then $\mathrm{L}_{\mathrm{m} 50}$ was estimated as the point on the $\mathrm{X}$-axis corresponding to $50 \%$ point on the $\mathrm{Y}$-axis.

\section{Age determination}

\section{RESULTS AND DISCUSSION}

Age was determined in 599 specimens of thin-lipped grey mullet $L$ ramada ranged from 11.6 to $45.8 \mathrm{~cm}\left(\mathrm{~L}_{\mathrm{t}}\right)$ and the corresponding weight was 28 to $668 \mathrm{~g}\left(\mathrm{~W}_{\mathrm{t}}\right)$. The length frequencies for all individuals are presented in Figure (2).

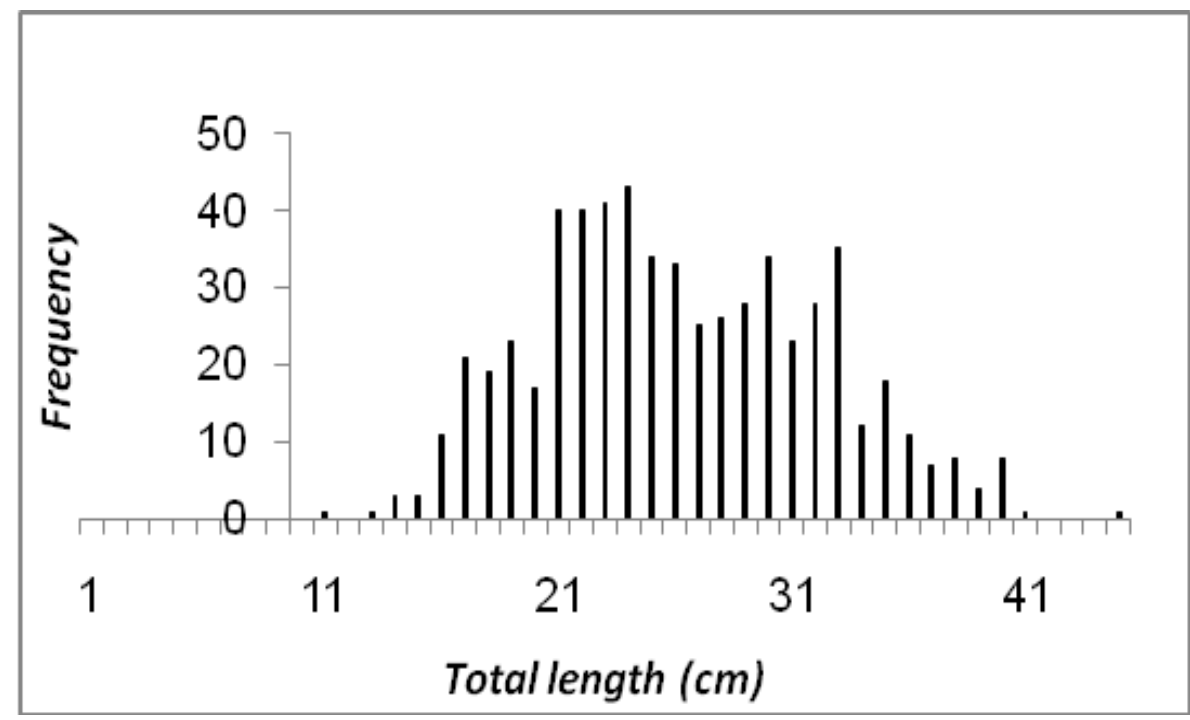

Fig. (2). Length-frequency distribution of $L$. ramada collected from Bardawil lagoon, during 2013.

The maximum length in the present study was close to that of Salem et al. (2010) who recorded $46.6 \mathrm{~cm}$, but more than that given by Mehanna (2006) who recorded $42 \mathrm{~cm}$ for the same species in Bardawil lagoon. Age-length key of L. ramada for all age classes are presented in Table (1). All fishes aged from 0 to 6 years. Most of the investigated fish were belonging to $1-3$ age classes $(\approx 80 \%)$.

Stock assessment is based on estimates of numbers of fish per age classes. All age-atlength data of the investigated stock are often combined without weighing, under the assumption that differences between gear types and regions can be disregarded (ICES, 2005). Young fish of L. ramada were high in Bardawil catch than other age classes, which may be caused by variation in length-at-age distributions or in the relative abundance in young fish or may be related to using non selective harmful fishing gear. The exploitation history of fish populations affects their demography and sustained heavy exploitation and results in truncated age structures by removing the largest (and presumably older) individuals (Ricker, 1969 ; Goni, 1998). 
Gaber I. Dessouky et al.

Table (1). Age - length key of $L$. ramada collected from Bardawil lagoon during 2013.

\begin{tabular}{|c|c|c|c|c|c|c|c|c|}
\hline \multirow{2}{*}{$\begin{array}{l}\text { Length } \\
\text { Interval }\end{array}$} & \multicolumn{7}{|c|}{ Age class (years) } & \multirow{2}{*}{ Total } \\
\hline & $\mathbf{0}$ & I & II & III & IV & $\mathbf{V}$ & VI & \\
\hline 11.5 & 1 & & & & & & & 1 \\
\hline 12.5 & & & & & & & & 0 \\
\hline 13.5 & 1 & & & & & & & 1 \\
\hline 14.5 & 3 & & & & & & & 3 \\
\hline 15.5 & 3 & & & & & & & 3 \\
\hline 16.5 & 6 & 5 & & & & & & 11 \\
\hline 17.5 & 4 & 17 & & & & & & 21 \\
\hline 18.5 & 2 & 17 & & & & & & 19 \\
\hline 19.5 & & 23 & & & & & & 23 \\
\hline 20.5 & & 17 & & & & & & 17 \\
\hline 21.5 & & 38 & 1 & 1 & & & & 40 \\
\hline 22.5 & & 31 & 8 & 1 & & & & 40 \\
\hline 23.5 & & 33 & 8 & & & & & 41 \\
\hline 24.5 & & 14 & 28 & 1 & & & & 43 \\
\hline 25.5 & & & 32 & 2 & & & & 34 \\
\hline 26.5 & & & 30 & 3 & & & & 33 \\
\hline 27.5 & & & 23 & 2 & & & & 25 \\
\hline 28.5 & & & 12 & 14 & & & & 26 \\
\hline 29.5 & & & 8 & 18 & 2 & & & 28 \\
\hline 30.5 & & & 2 & 29 & 3 & & & 34 \\
\hline 31.5 & & & & 17 & 6 & & & 23 \\
\hline 32.5 & & & & 16 & 12 & & & 28 \\
\hline 33.5 & & & & 19 & 16 & & & 35 \\
\hline 34.5 & & & & 2 & 10 & & & 12 \\
\hline 35.5 & & & & 3 & 14 & 1 & & 18 \\
\hline 36.5 & & & & 2 & 8 & 1 & & 11 \\
\hline 37.5 & & & & 1 & 2 & 3 & 1 & 7 \\
\hline 38.5 & & & & & 2 & 4 & 2 & 8 \\
\hline 39.5 & & & & & & 3 & 1 & 4 \\
\hline 40.5 & & & & & & 4 & 4 & 8 \\
\hline 41.5 & & & & & & 1 & & 1 \\
\hline 42.5 & & & & & & & & 0 \\
\hline 43.5 & & & & & & & & 0 \\
\hline 44.5 & & & & & & & & 0 \\
\hline 45.5 & & & & & & & 1 & 1 \\
\hline Length & 16.1 & 21.2 & 26.0 & 30.9 & 34.0 & 38.9 & 40.2 & 599 \\
\hline$N$ & 20 & 195 & 152 & 131 & 75 & 17 & 9 & 599 \\
\hline
\end{tabular}

\section{The length - weight relationship}

The length - weight relationship of a fish can be described by a cube law $\mathrm{W}=\mathrm{aL}^{3}$ (where $\mathrm{W}=$ weight of fish in $\mathrm{g}, \mathrm{L}=$ length of fish in $\mathrm{cm}$ and $\mathrm{a}=$ constant). The cube law represents a condition in an ideal fish, where in the fish maintains constant shape (Allen, 1938). Generally, the length-weight relationship is affected by various factors as the availability of food, rate of feeding, development of gonads, spawning...etc. Therefore, length-weight equation should include fishes of both sexes which sampled at various times of the year to be most useful. Figure (3) showed the length-weight relationship of 599 individual of L. ramada in the Bardawil lagoon. In the present study, the value of (b) for L. ramada was about 2.764 during the fishing season 2013 which represented by the equation:

$$
\mathrm{W}=0.017 \mathrm{~L}^{2.764} \text {. }
$$




\section{Age, growth and maturity of the thin-lipped grey mullet, liza ramada in Bardawil lagoon, North Sinai, Egypt}

This indicated that the growth in weight is negative allometric (the weight did not follows the cube of length). Moreover, the $b$ value of the length-weight relationship in this study differs from those found by Mehanna (2006) $(\mathrm{b}=3.13)$ for L ramada in Bardawil lagoon. The length-weight relationship for L. ramada in the present study is higher than that obtained by Kasimoglu et al. (2011) $(\mathrm{b}=2.253)$ for L. ramada in Turkey (the Southern Aegean Sea). Enin (1994) mentioned that the parameter b is equal to 3 at isometric growth, when it is less or greater than 3 it is allometric. Bagenal and Tech (1978) mentioned that, length-weight relationship is a practical index of the condition of fish and varies over the year according to factors such as food availability, feeding rate, gonad development and spawning period.

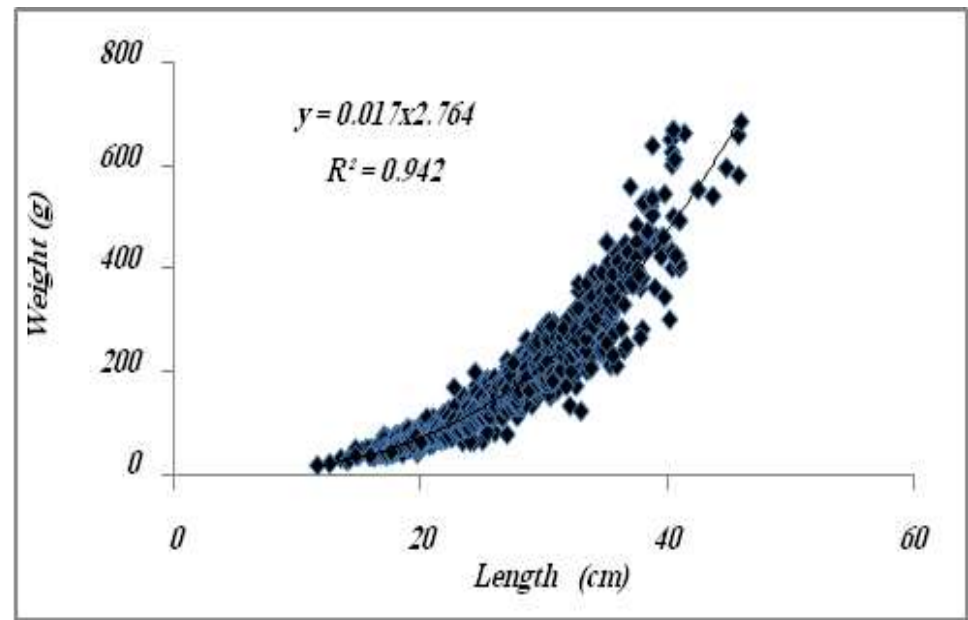

Fig. (3). Length-weight relationship of $L$. ramada collected from Bardawil lagoon during 2013.

\section{Back - calculation}

To estimate previous growth history of $L$. ramada, the relationship between scale radius and the total length was studied by back - calculation (Table 2).

Table (2). Back - calculated lengths at the end of different years of life of L. ramada collected from Bardawil lagoon during 2013.

\begin{tabular}{cclllllll}
\hline \multirow{2}{*}{ Age } & \multirow{2}{*}{$\begin{array}{c}\text { no. } \\
\text { of fish }\end{array}$} & \multirow{2}{*}{ Obs. length } & \multicolumn{6}{c}{ Average back calculated lengths at the end of age years ( cm) } \\
\cline { 4 - 8 } & & I & II & III & IV & V & II \\
\hline $\mathbf{0}$ & 20 & 16.1 & & & & & & \\
I & 195 & 21.1 & $\underline{\mathbf{1 6 . 9}}$ & & & & & \\
II & 152 & 25.9 & 16.7 & $\underline{\mathbf{2 3 . 1}}$ & & & & \\
III & 131 & 30.8 & 16.7 & 23.6 & $\underline{\mathbf{2 8 . 3}}$ & & & \\
IV & 75 & 34 & 15.2 & 22.2 & 27.5 & $\underline{\mathbf{3 2}}$ & & \\
V & 17 & 38.8 & 13.3 & 20.8 & 26.4 & 31.1 & $\underline{\mathbf{3 5 . 3}}$ & \\
VI & 9 & 40.2 & 14.5 & 21.5 & 26.9 & 31.4 & 35.1 & $\underline{\mathbf{3 8 . 3}}$ \\
\hline & $\underline{\mathbf{5 9 9}}$ & $\underline{\text { Increment }}$ & $\underline{\mathbf{1 6 . 9}}$ & $\underline{\mathbf{6 . 2}}$ & $\underline{\mathbf{5 . 2}}$ & $\underline{\mathbf{3 . 7}}$ & $\underline{\mathbf{3 . 3}}$ & $\underline{\mathbf{3}}$ \\
\hline
\end{tabular}


Gaber I. Dessouky et al.

The back-calculated lengths were 16.9, 23.1, 28.3, 32, 35.5 and $38.3 \mathrm{~cm}$ corresponding to ages $1^{\text {st }}, 2^{\text {nd }}, 3^{\text {th }}, 4^{\text {th }}, 5^{\text {th }}$ and $6^{\text {th }}$, respectively. The lengths at the end of years of $L$. ramada in Bardawil lagoon, 2013 were smaller, especially for older fish comparing with similar studies by Mehanna (2006) (back-calculated lengths were 21.09, 30.05, 36.33, 39.26 and $41.08 \mathrm{~cm}$ at ages I, II, III, IV and V years, respectively) and Salem et al. (2010) who found that, the back - calculated lengths were 19.3,27, 32.3, 36.1, 39.3 and $42.2 \mathrm{~cm}$ at ages $1^{\text {st }}, 2^{\text {nd }}, 3^{\text {rd }}, 4^{\text {th }}, 5^{\text {th }}$ and $6^{\text {th }}$, respectively. The highest annual increment in the present study occurred at first year of life $16.9 \mathrm{~cm}$, while, beyond this age, the growth rate slows down to $\approx$ 3: $6 \mathrm{~cm}$ per year.This change in value was identifying by similar studies. The lowest of growth was related to slower growing individuals with highly exploited and disturbances by fishing boats. Environmental conditions and availability and type of food resources could affect fish growth rates and thus lengths at age (Wootton, 1990)

The back-calculated weights at the end of years for Liza ramada in Bardwil lagoon were estimated by applying the equation of length-weight relationship as illustrated in Table (3).

Table (3). Average and increment of weight at the end of different years of $L$. ramada collected from Bardawil lagoon during 2013.

\begin{tabular}{|c|c|c|c|c|c|c|c|c|}
\hline \multirow{2}{*}{ Age } & \multirow{2}{*}{$\begin{array}{r}\text { no. } \\
\text { of fish }\end{array}$} & \multirow{2}{*}{$\begin{array}{c}\text { Obs. } \\
\text { weight }\end{array}$} & \multicolumn{6}{|c|}{ Average and increment of weight at the end of each year ( $\mathrm{gm}$ ) } \\
\hline & & & I & II & III & IV & $\mathbf{V}$ & VI \\
\hline 0 & 20 & 42.4 & & & & & & \\
\hline I & 195 & 80.4 & $\underline{43.8}$ & & & & & \\
\hline II & 152 & 142.9 & 42.2 & $\underline{102.5}$ & & & & \\
\hline III & 131 & 220.3 & 42.1 & 109.7 & $\underline{179.7}$ & & & \\
\hline IV & 75 & 285.3 & 32.4 & 92.4 & 166.9 & $\underline{254.4}$ & & \\
\hline V & 17 & 444.8 & 22.5 & 76.7 & 148.3 & 234.4 & $\underline{\mathbf{3 3 1 . 3}}$ & \\
\hline \multirow[t]{2}{*}{ VI } & 9 & 548.6 & 28.2 & 84.6 & 156.4 & 241.2 & 328.1 & $\underline{417.6}$ \\
\hline & 599 & Increment & $\underline{43.8}$ & $\underline{58.8}$ & $\underline{77.2}$ & $\underline{74.7}$ & $\underline{76.9}$ & $\underline{86.3}$ \\
\hline
\end{tabular}

The increasing of weight is very important than increasing of length for fishermen, where the landings are recorded as a weights. The back-growth was calculated as 43.8, 102.5, 179.7, 254.4, 331.3, and 417.6g at the end of $1^{\text {st }}, 2^{\text {nd }}, 3^{\text {rd }}, 4^{\text {th }}, 5^{\text {th }}$ and $6^{\text {th }}$ years of life, respectively. Mehanna (2006) recorded that, the back calculated weights were 73.39, 222.6, $403.5,514.57$ and $593 \mathrm{gm}$. for ages $1^{\text {st }}, 2^{\text {nd }}, 3^{\text {rd }}, 4^{\text {th }}$ and $5^{\text {th }}$ years respectively. Salem et al. (2010) found that the back calculated weights were 63.63, 160.2, 262.9, 357.5, 452.1 and 550.4 at ages $1^{\text {st }}, 2^{\text {nd }}, 3^{\text {rd }}, 4^{\text {th }}, 5^{\text {th }}$ and $6^{\text {th }}$, respectively. In the present study, the growth was lower than that previous study indicating that, the environmental factors unsuitable during the study period.

\section{Theoretical growth}

In the present study, the Von-Bertalanffy growth parameters of $L$. ramada were $L \infty=50.95$ $\mathrm{cm}, \mathrm{K}=0.1977 \mathrm{yr}^{-1}, \mathrm{t}_{0}=-1.04 \mathrm{yr}^{-1}$. The growth parameters and lifespan in the present results 


\section{Age, growth and maturity of the thin-lipped grey mullet, liza ramada in Bardawil lagoon, North Sinai, Egypt}

were lower than that obtained by Sinovcic et al. (1986) in Adriatic Sea for the same species $\left(\mathrm{L}_{\infty}=52.5 \mathrm{~cm}, \mathrm{~K}=0.25 \mathrm{yr}^{-1}\right.$ and $\left.\mathrm{t}_{0}=-0.1 \mathrm{yr}^{-1}\right)$ of about $8 \mathrm{yr}$. The low $\mathrm{L} \infty$ may be due to the over fishing in the lagoon at the last period, and the rarity of larger and older individuals within the landings. Parsons (1982) stated that, in general, the older the year class, the higher the L $\infty$ value.

The growth coefficient $(\mathrm{K})$ is related to the longevity of fish. In the present study, the growth coefficient $(\mathrm{K})$ is lower comparing with the similar previous studies. Mehanna (2006) in Bardawil lagoon of the same species recorded that $\mathrm{K}=0.51 \mathrm{yr}^{-1}$. The $\mathrm{K}$ value (determines how fast the fish approaches its L $\infty$ ) contributed with the lifespan of fish and fast growth. Therefore, this parameter affected by growth factors such as food availability and environmental factors.

The growth performance $(\varphi)$ in the present study for L.ramada was $(\varphi=2.71)$ slightly higher than that estimated for the same species in lake Borollus $(\varphi=2.66)$ (Hosny and Hashem, 1995). On the other hand, it was lower than $(\varphi=2.91)$ for the same species at Wadi El- Raiyan lakes (EL Gammal and Mehanna, 2004), ( $\varphi=2.98)$ at Lake Timsah (Mehanna and Amin, 2005) and $(\varphi=3.0)$ in Bardawil lagoon (Mehanna, 2006). This result is close to that of Salem et al. (2010) in Bardawil lagoon for the same species $(\varphi=2.84)$. The differences in growth performance $(\varphi)$ is related to temperature (Ricker, 1975), salinity (Popper and Gundermann, 1975) and possibly to differences in food items (Golani,1993).

\section{Condition factor}

The condition indices portrayed by morphometric measurements represent a basis for developing an explanatory hypothesis about biological responses or different ecological scenarios for populations (Liao et al., 1995). The condition factor (Kc) is used for comparing the condition, fatness, or well-being of fishes (Mir et al., 2012).In the present study, the condition factor of $L$. ramada was recorded according to seasonality and different lengths (Fig. 4).

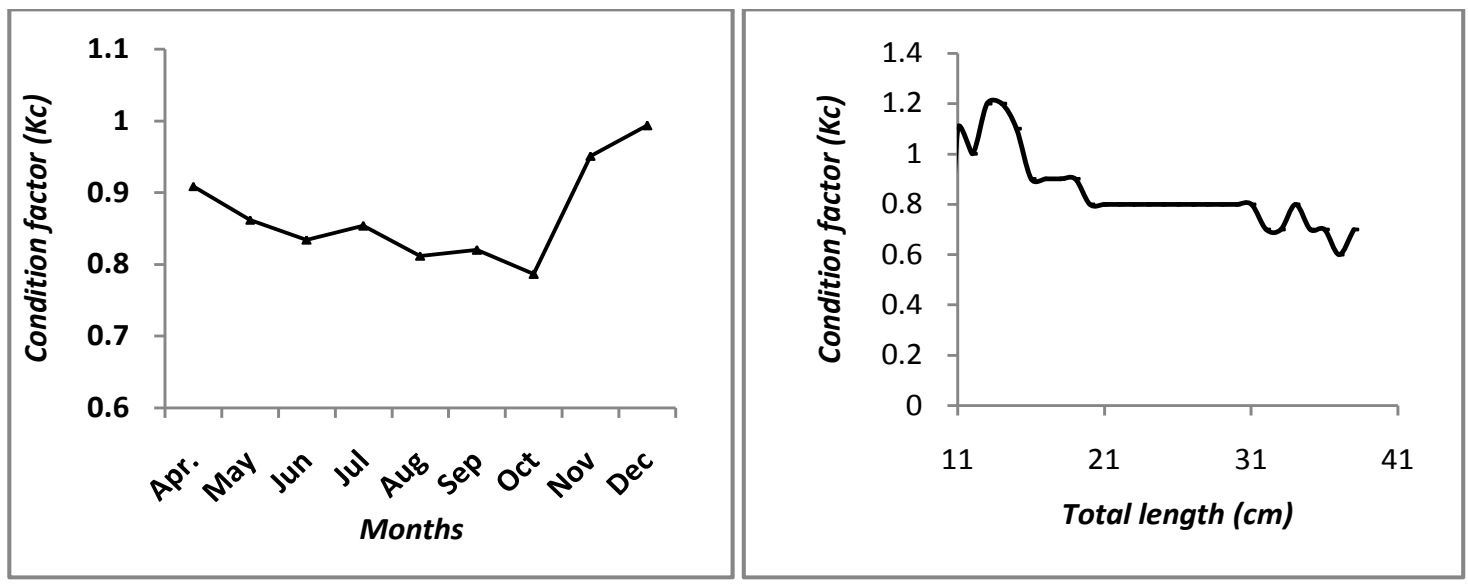

Fig. (4). Relationship between Kc values and months and the total length intervals of life of $L$. ramada collected of Bardawil lagoon during 2013. 
Gaber I. Dessouky et al.

The highest value of condition factor $(\mathrm{Kc})$ in the present study was recorded in April, declined from May until October and started to increase during November and December.The higher Kc values in April may be due to closing period in the Bardawil lagoon, where the fishing season starting in mid April. After opening of fishing season, growth in fish may be affected by stress of vessels noise, which decreases fish feeding activity. Davidson et al. (2009) noted that, a growth rate of rainbow trout was slower during the first month of noise exposure; however fish acclimated to the noise thereafter. Noise in the environment can lead to reduce food consumption (Voellmy et al., 2014). Increasing of condition factor (Kc) values at November and December and with older fish (more than $30 \mathrm{~cm}$ ) may be due to increasing in somatic growth and gonad maturation and onset maturity. In Bardawil lagoon, the size at maturity of $L$. ramada was $\approx 29 \mathrm{~cm}\left(\mathrm{~L}_{\mathrm{t}}\right)$. The condition factors can be attributed to the richness of nutrients, population density, age and spawning season (kasimoglu et al., 2011).

\section{Sex ratio}

A total of 215 males (35.9\%) and 384 females (64.1\%) of thin-lipped grey mullet $L$. ramada were sexed by opening the abdomens and examining the gonads. The percent of males to females with age classes are illustrated in Table (4).

Table (4). Sex ratio of $L$. ramada collected from Bardawil lagoon during 2013.

\begin{tabular}{lllll}
\hline \multirow{2}{*}{ Age } & \multicolumn{2}{c}{ Males } & \multicolumn{3}{c}{ Females } \\
\cline { 2 - 5 } & $\mathbf{N}$ & \% & $\mathbf{N}$ & \% \\
\hline 0 & 9 & 45.0 & 11 & 55.0 \\
I & 67 & 34.4 & 128 & 65.6 \\
II & 55 & 36.2 & 97 & 63.8 \\
III & 52 & 39.7 & 79 & 60.3 \\
IV & 26 & 34.7 & 49 & 65.3 \\
V & 4 & 23.5 & 13 & 76.5 \\
VI & 2 & 22.2 & 7 & 77.8 \\
\hline Average & & 33.7 & & 66.3 \\
\hline
\end{tabular}

Gonads of 599 specimens of $L$. ramada were examined for sex ratio determination. It was $\approx 1: 2$ male to female, respectively. El-Halfway et al. (2007) reported sex ratio of $L$. ramada in Lake Timsah as 1:1.7 males to females, respectively. Also, they observed that, the sex ratio is not constant throughout the different months.

\section{Gonado-somatic index}

The reproductive activity of $L$. ramada started in September with a peak in December as it has the highest GSI values for males and females of L. ramada (Fig. 5).

The age and size at sexual maturity may be important in assessing the optimum age of first capture of a species and the time and place of spawning and can be used to plan fishing tactics. Most of samples, which collected in November and December, were matured. These result was close to that given by El-Halfway et al. (2007), as the spawning season of Liza ramada in Timsah Lake extended from November to January. The spawning season of $L$. ramada in Turkey occurred between October and December, showing a peak in November (Ergene, 2000 and Kasimoglu et al., 2011). 


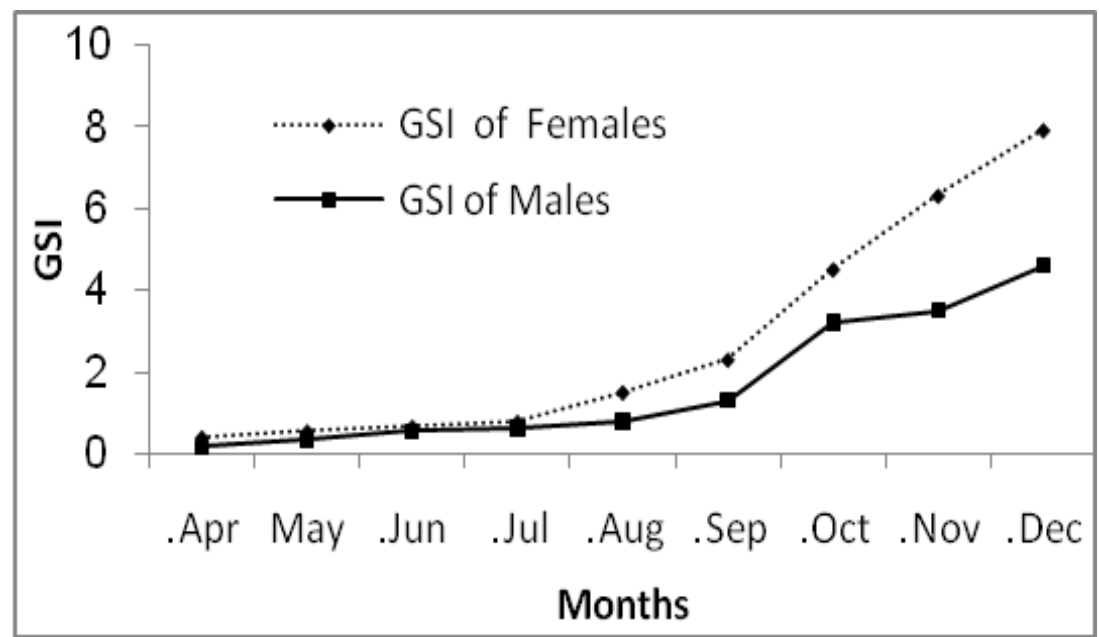

Fig. (5). Monthly variation of GSI values for males and females of life of $L$. ramada collected from Bardawil lagoon during 2013.

\section{Length at first sexual maturity}

The length at which $50 \%\left(\mathrm{~L}_{\mathrm{m} 50}\right)$ of individuals attained sexual maturity was $28.6 \mathrm{~cm}$ $(\approx 3.1$ years $)$ and $29.6 \mathrm{~cm}(\approx 3.4$ years) for males and females, respectively (Fig. 6$)$.

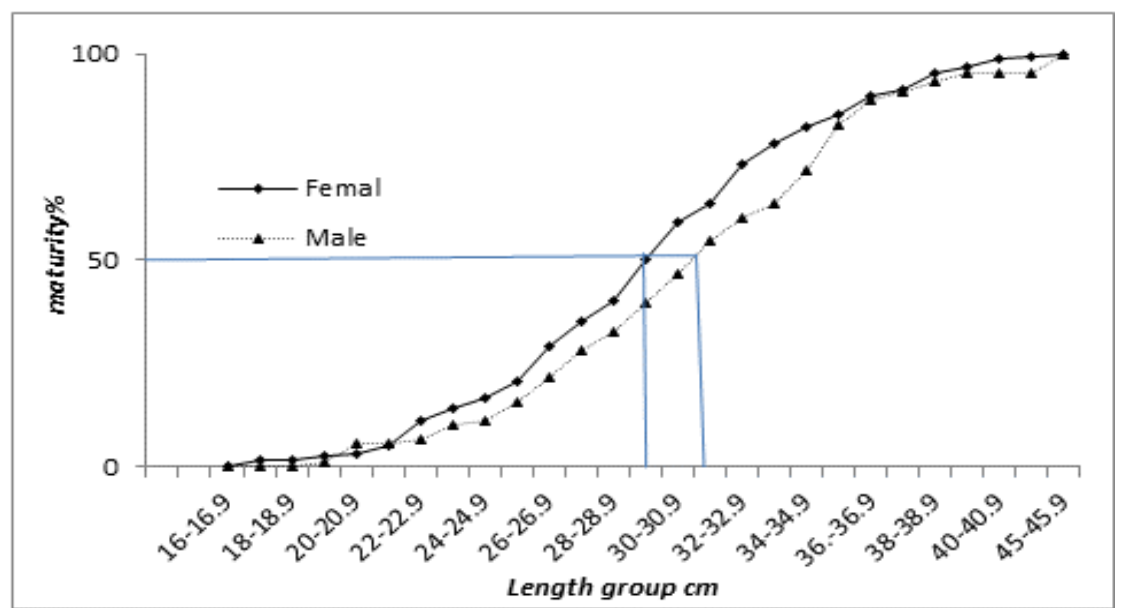

Fig. (6). $L_{m 50}$ of $L$. ramada (males and female) collected from Bardawil lagoon during 2013.

Ergene (2000) recorded the age of sexual maturity for L. ramada as three years in Akgöl-Paradeniz lagoons, Turkey. This age at first maturity value was the same as the present results. Immature individuals of this species are represent by $43 \%$ of the total catch, so it could be mentioned that the fishing gear in the lagoon is of medium harmful to this species according to Cetini et al.(2002) who mentioned that, if the percentage of immature specimens in total catch is above $50 \%$, fishing gear would be considered as very harmful, if it is between 
Gaber I. Dessouky et al.

20 and $50 \%$, it is considered as medium harmful, and if it is under $20 \%$ then the harmful influence of fishing gear is acceptable.

The present results recommended protecting this species during the spawning season in November - December period; at least near of inlets (Boughazis) between the lagoon and Mediterranean Sea, in order tosecure future spawning.

\section{REFERENCE}

Allen. K. R. (1938). Some observations on the biology of the trout Salmo trutta in Windermere. J. Anim. Ecol., 7: 333-349.

Bariche, M.; Harmelin,V.M. and Quignard, J.P. (2003). Reproductive cycles and spawning periods of two Lessepsian siganid fishes on the Lebanese coast. J. Fish Biol., 62:129142.

Begenal, T.B. and Tesch, F.W. (1978). Age and growth In: T. Bagena, editor, methods for assessment of fish production in fresh waters . IBp handbook No.3 $\left(3^{\text {rd }}\right.$ ed) Black well scientific publications, oxford. pp 101-136 (chapter 5).

Cetini, P.; Soldo, A.; Dul, J. and pallaoro, A. (2002). Specific method of fishing for sparidae species in the eastern Adriatica . Fish. Res., 55:(1-3):131-139.

Davidson, J.; Bebak, J. and Mazik, P. (2009. The effects of aquaculture production noise on the growth, condition factor, feed conversion, and survival of rainbow trout, Oncorhynchus mykiss. Aquacult., 288: 337-343.

El-Gammal, F. I. and Mehanna, S.F. (2004).The dynamics and exploitation of the population of Liza ramada (Risso, 1810) in Wadi EI-Raiyan lakes. Egypt. J. Aquat. Biol. Fish., 8(3): 35-51.

EL-Halfawy, M.; Ramadan, A. M. and Mahmoud W.F. (2007). Reproductive biology and histological studies of the grey mullet, Liza ramada, (RISSO, 1826) in Lake Timsah, Suez Canal. Egypt. J. Aquat. Res., 33(1): 434-454.

Enin, U. (1994). Length-weight parameters and condition factor of two West African prawns. Rev. Hydrobiol. Trop., 27: 121-127.

Ergene, S. (2000). Reproduction Characteristics of Thinlip Grey Mullet, Liza ramada (Risso, 1826) Inhabiting Akgöl-Paradeniz Lagoons (Göksü Delta), Turkey J. Zool., 24: 159_ 164.

Golani, D. (1993). The sand shore of the red sea-launching pad for lessepsian (Suze Canal) migrant fish colonizers of the eastern Mediterranean. J. Biogeoger., 20: 579-85.

Goni, R. (1998). Ecosystem effects of marine fisheries: an overview. Ocean and Coast. Manag., 40: 37-64.

Gulland, J. A. and Holt, S. L., 1959. Estimation of growth parameters for data at unequal time intervals. J. cons. Perm. Int. Explor. Mer., 25 (1): 47 - 49.

Hile, R. (1936). Age and growth of the Cisco, Leucichthy sartedi (Le Sueur) in the lakes of the Northeastern high-lands, Wisconsin. Bull. Bur. Fish. U.S., 48(19): 211-317.

Hosny, C.F.H. and Hashem, M.T. (1995). Biology of growth of Liza ramada in Lake Borollus. Egypt. Bull. Nat. Inst. Oceanog. Fish., ARE, 21(2):469-475.

ICES (2005). International Council for the Exploration of the Sea 2005. Report of the Working Group on the Assessment of Northern Shelf Demersal Stocks (WGNSDS), Murmansk, Russia.

Kasimoğlu, C.; Yilmaz, F. and Koc, H. T. (2011).Growth and Reproductive characteristics of the Thin-lipped Grey Mullet, Liza ramada (Risso, 1826) Inhabiting in Gökova Bay (Muğla), the Southern Aegean Sea, Turkey. BA- Fen Bil. Enst. DergisiCilt., 13(2): 3549. 


\section{Age, growth and maturity of the thin-lipped grey mullet, liza ramada in Bardawil lagoon, North Sinai, Egypt}

Lea, E. (1910). On the methods used in the herring investigations. Publ. Circonstance, Cons. Int. Explor. Mer., 53: 7-174.

Liao, D. N.A. and Hessler, R. (1995). Malinow activation of post-syntically silent synapses during pairing-induced LTP in CA1 of hippocampal slice. Nature, 375:400-404.

Mehanna, S. F. and Amin, A. M. (2005). Population dynamics of the Thinlip mullet Liza ramada in Lake Timsah, Egypt, International Conference on Aquatic Resources of the Arab Region, NIOF, 7-91h May.

Mehanna, S.F. (2006). Fisheries management of the thinlip grey mullet Liza ramada and golden grey mullet liza aurata from lake Bardawil, Egypt. J. Aquat. Biol. Fish., 10(2): $33-53$.

Mir, J. I.; Sarkar, U.K.; Dwivedi, A.K.; Gusain, O.P.; Pal, A. and Jena, J.K. (2012). Pattern of Intrabasin Variation in Condition Factor, Relative Condition Factor and Form Factor of an Indian Major Carp, Labeo rohita (Hamilton-Buchanan, 1822) in the Ganges Basin, India. Europ. J. Biol. Sci., 4 (4): 126-135.

Nelson, J.S. (1994). Fishes of the World, $4^{\text {th }}$ Edition. John Wiley and Sons, Inc. Hoboken, New Jersey, USA 601 PP.

Parsons, C. (1982). Biology of bass, Dicentrarchus labrax (L) from south-west wales. part II honours project, Univ. of Walse, 66p.

Paul, L. J. (1968). Early scale growth characteristics of the New Zealand, Sparus aurita (Forster), with reference to selection of a scale - sampling site. N.Z.J. Marine and Fresh water Res., 2: $273-292$.

Pauly, D. and Munro, J.L. (1984). Once more on growth compares in fishes and invertebrates. Fish byte, 2 (1): 21.

Popper, D. and Gundermann, N. (1975). Some ecological and behavioural aspects of siganid populations in the Red Sea and Mediterranean coasts of Israel in relation to their suitability for aquaculture. Aquacult., 6:127-141.

Ricker, W. E. (1969). Effects of size-selective mortality and sampling bias on estimates of growth, mortality production and yield. J. Fish. Res. Board of Canada, 26: 479-541.

Ricker, W. E. (1975). Computation and interpretation of biological statistics of fish populations. Bull. Fish. Res. Board Canada, 191:382.

Salem, M.; EL Aiatt, A. A. and Ameran, M. (2010). Age, growth, mortality and yield per recruit of Liza ramada in Bardawil lagoon, North Sinai, Egypt. Abbassa Inter. J. Aquacult.,(The third scientific Conference, Al Azhar University, Cairo $17-18$ October) .

Sinovcic, G.; Alegria-Hernandez, V.; Jug, D. J.; Jukic, S.; Kacic, I.; Regner, S. and Tonkovic, M. (1986). Contribution to the knowledge of ecology of grey mullet; Liza ramada (Risso, 1826) from the middle Adriatic (Sibenik area). Acta Adriatica, 27:147-162.

Voellmy, I. K.; Purser, J.; Flynn, D.; Kennedy, P.; Simpson, S. D. and Radford, A. N. (2014). Acoustic noise reduces foraging success in two sympatric fish species via different mechanisms. Anim. Behavior, 89: 191-198.

Wootton, R. J. (1990). Ecology of Teleost Fishes. New York: Chapman \& Hall. 
Gaber I. Dessouky et al.

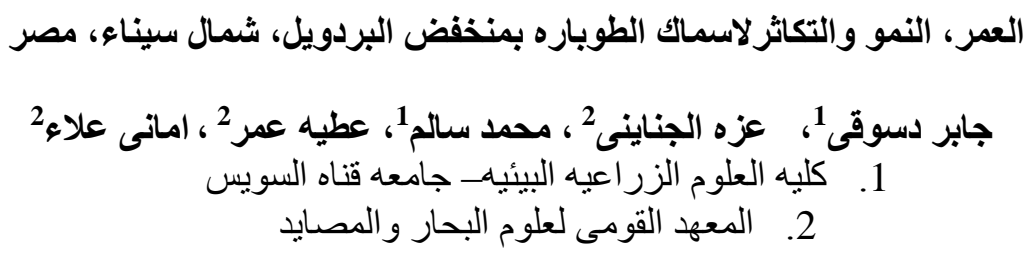

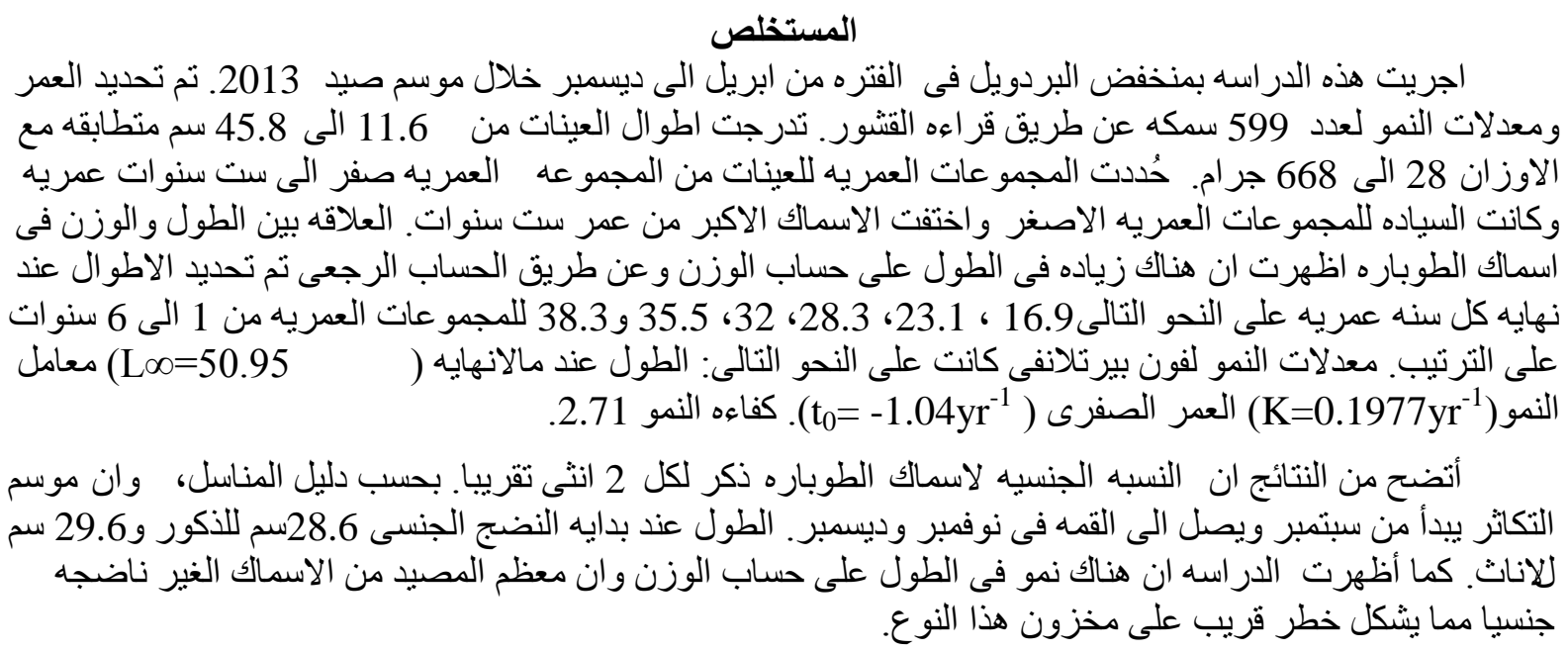

